\title{
The small species of Belostoma Latreille (Heteroptera, Belostomatidae). III. A revision of oxyurum group, with a new species from Brazil and description of the male of $B$. noualhieri Montandon
}

\author{
José Ricardo I. Ribeiro ${ }^{1}$ \& Ana L. Estévez ${ }^{2}$
}

${ }^{1}$ Centro de Ciências Rurais, Campus São Gabriel, Universidade Federal do Pampa, Av. Antônio Trilha, 1847, 97300-000 São Gabriel-RS, Brasil. belostom@acd.ufrj.br

${ }^{2}$ Museo de La Plata. División Científica de Entomologia. Paseo Del Bosque s/nº, B1900FWA La Plata, Buenos Aires, Argentina. anitaestevez@argentina.com

\begin{abstract}
The small species of Belostoma Latreille (Heteroptera, Belostomatidae). III. A revision of oxyurum group, with a new species from Brazil and description of the male of B. noualhieri Montandon. Species of the oxyurum group (sensu Lauck) consist of five extant Neotropical small species, whose lengths range 15.0 to $20.0 \mathrm{~mm}$. The anterior interocular width about 1.5 times the width of an eye and ventral diverticulum of phallus flattened, circular, and large are, in combination, diagnostic. The small species of the oxyurum group were included in the Lauck's key to the identification of the species groups, without dealing with the species included in it because many of them are very similar in appearance. Therefore here we redescribe and key the Belostoma species of the oxyurum group. Belostoma oxyurum (Dufour) is newly recorded from Brazil (Paraná and Rio Grande do Sul). Holotype and lectotype are designated for B. oxyurum and B. sanctulum Montandon, respectively. The aspect of the prosternal keel, the ratio between the width of the ventral diverticulum of phallus and its length in ventral view, and the aspect of dorsal arms of ventral diverticulum have proven useful for better species delimitation. Based on specimens from Pará State (N. Brazil), Belostoma carajaensis Ribeiro \& Estévez, sp. nov. is described and illustrated. This new species differs from B. sanctulum in having anteoculus shorter than interoculus and the dorsal arms of ventral diverticulum divergent and large. A male specimen of B. noualhieri Montandon was collected in São Paulo State and based mainly on features of male genitalia, this species is here also included under oxyurum group.
\end{abstract}

KEYWORDS. Neotropics; Nepomorpha; systematic; water bug.

RESUMO. Espécies de Belostoma Latreille (Heteroptera, Belostomatidae) de pequeno porte. III. Revisão do grupo oxyurum com uma nova espécie do Brasil e a descrição do macho de B. noualhieri Montandon. Representantes do grupo oxyurum (sensu Lauck) compreendem cinco espécies neotropicais de pequeno porte, com comprimento total do corpo entre 15,0 e $20,0 \mathrm{~mm}$. A largura interocular anterior cerca de uma vez e meia a largura de um olho e os formatos achatado, circular e alargado do divertículo ventral do falossoma são característicos de seus representantes. Esse grupo de espécies foi incluído na chave de identificação de Lauck para grupos de espécies de Belostoma Latreille, mas seus representantes não tiveram sua taxonomia detalhada por serem espécies com proximidade morfológica grande. Neste trabalho, as espécies do grupo oxyurum são redescritas e uma chave de identificação para suas espécies é fornecida. É registrada pela primeira vez no Brasil a espécie $B$. oxyurum (Dufour) nos estados do Paraná e do Rio Grande do Sul. Um holótipo e um lectótipo foram designados para B. oxyurum e B. sanctulum Montandon respectivamente. O aspecto da carena prosternal, a relação entre a largura do divertículo ventral do falossoma e seu comprimento em vista ventral e o aspecto dos braços dorsais do divertículo ventral mostraram-se importantes na melhor definição das espécies do grupo. Belostoma carajaensis Ribeiro \& Estévez, sp. nov. é descrita e ilustrada com base em espécimes do Estado do Pará, norte do Brasil e se diferencia de $B$. sanctulum pelo comprimento do anteóculo menor que o do interóculo e pelos braços dorsais do divertículo ventral divergentes e largos. Um espécime macho de B. noualhieri Montandon foi coligido no Estado de São Paulo e, baseado principalmente nas características observadas da genitália masculina deles, essa espécie é aqui incluída no grupo oxyurum.

PALAVRAS-CHAVE. Barata d'água; Nepomorpha; Região Neotropical; sistemática.

Lauck (1962) recognized small, medium and moderately large or large species as size categories of the species belonging to the genus Belostoma Latreille,1807. Lauck (1962, 1963, 1964) described medium, moderately large and large size species, basing his work mainly on morphology of male genitalia.

Lauck (1962) included oxyurum group as one of the small species group in the key to the identification of the species groups, without dealing with the species included in it. This group is widely distributed in South America, showing particular assemblage in southeastern and southern Brazil, but is scarcely represented in northern Mesoamerica; only $B$. aztecum Lauck, 1959 occurs in Mexico and El Salvador (Lauck 1959).

During a revisional study of Belostoma species occuring in southeastern Brasil, Ribeiro (2007) treated with four of the five species included in oxyurum group. This author considered for the descriptions of the species those characters used by De Carlo (1930, 1938, 1957), Schnack (1976), and those proposed by Estévez \& Polhemus (2001). Belostoma noualhieri Montandon, 1903, however, was poorly treated in 
the revisional study of Ribeiro (2007), as well as in De Carlo (1938), as it was described based only on one female from Rio Grande do Sul State, Brazil. Up to the present there is no description of the male for this species.

In the present paper, a male of $B$. noualhieri and a new Belostoma species are described based on specimens from São Paulo and Pará states, Brazil, respectively, being herein included under oxyurum group. In addition, it is described and figured the other following five species: B. aztecum; $B$. candidulum Montandon 1903; B. horvathi Montandon 1903, B. oxyurum (Dufour, 1863), and B. sanctulum Montandon 1903.

\section{MATERIALAND METHODS}

The results presented herein are based on specimens deposited in the following institutions: BMNH (The Natural History Museum, London, England); CASC (California Academy of Sciences, San Francisco, USA); ISNB (Institut Royal des Sciences Naturelles de Belgique, Brussels, Belgium); JADZRJ (Coleção Entomológica Prof. José Alfredo Pinheiro Dutra, Departamento de Zoologia, Instituto de Biologia, Universidade Federal do Rio de Janeiro, Rio de Janeiro, Brazil); JTPC (John T. Polhemus Collection, Denver, USA); LACM (Los Angeles County Museum, Los Angeles, USA); MACN (Museo Argentino de Ciencias Naturales "B. Rivadavia", Buenos Aires, Argentina); MLPA (Museo de La Plata, La Plata, Argentina); MNHN (Museum National d'Histoire Naturelle, Paris, France); MNRJ (Museu Nacional, Universidade Federal do Rio de Janeiro, Rio de Janeiro, Brazil); NHRS (Naturhistoriska Riksmuseet, Stockolm, Sweden); SEMC (Francis Huntington Snow Entomological Collections, Kansas University, Lawrence, USA); and UA (University of Arizona, Tucson, USA). HNHM (Hungarian Natural History Museum, Budapest, Hungary) and NHMW (Naturhistorisches Museum Wien, Vienna, Austria) are the acronyms of the collections presented only in the type data.

In quotations of label data, a comma separates different information and a period mark separates information on different specimens. The full citation of individual specimens collected at the same locality on different dates is not cited. A semicolon separates different specimens with same information. Insect collection institutions and collectors are cited inside parentheses. The letter " $m$ " refers to male specimens and the letter " $\mathrm{f}$ " to female ones. All the localities are organized by north to south order. Full official names of subdivisions are presented with their shorter common names, as proposed by Zanella et al. (2000).

Taxonomic characters used in the descriptions are the same mentioned by Estévez \& Polhemus (2001) and Ribeiro (2007).

\section{RESULTS}

\section{The oxyurum group}

Measurements. - Total length (from apex of head to apex of hemelytra at rest), 12.0-21.2 mm; greatest width of body, 5.5$10.1 \mathrm{~mm}$. General coloration uniformly brown.
Head, thorax, and abdomen. - Clypeus reaching ocular line; vertex without longitudinal median carina; eyes globose, as wide as long. Greatest pronotal width shorter than its length; scutellum not reaching nodal line, without longitudinal median carina. Pilosity of connexivum well developed, covering half (slightly constricted between spiracles) or entire margin of connexivum (ventral laterotergites) and part of sternites, well or slightly developed on penultimate visible segment (Figs. $16-20,44)$.

Male genitalia (Figs. 21-35, 36-38, 40-42).Ventral diverticulum of phallus flattened, circular and broad, without dorsal caudal protuberance in dorsal and lateral views, without depression in mid dorsal line, without developed ventroapical protuberance in lateral and ventral views, and truncated at apex in ventral view; caudal laterodorsal margins without prominent thickenings in dorsal view.

Remarks. - The flat and broad ventral diverticulum resembles the male genitalia of the species belonging to denticolle group (sensu Estévez \& Polhemus), but the presence of a well developed abdominal pilosity in oxyurum group species (rather than poorly developed as in denticolle and plebejum group ones) is sufficiently morphologically distinct.

Key to the species of oxyurum group (with new species included).

1. Pilosity extending posteriorly along less than half of genital operculum (Figs. 17-20) .................................... 3

Pilosity extending posteriorly along about half length of genital operculum (Figs. 16, 44) .................................... 2

2. Pilosity extending along genital operculum, covering entire margin of connexivum and part or all of sternites (Fig. 44) ........ B. noualhieri Montandon (Figs. 40-44) (Brazil: Rio Grande do Sul, Santa Catarina, São Paulo)

Pilosity extending far away genital operculum, covering part of connexivum (Fig. 16) .......... B. oxyurum (Dufour) (Figs. 1, 6, 11, 16, 21, 26, 31) (Argentina: Buenos Aires, Chascomús, Entre Ríos, Martín García Island, Martínez, Tigre; Brazil: Paraná, Rio Grande do Sul; Uruguay: Maldonado, Montevideo)

3. Prosternal keel acutely angulate, usually anteriorly projected (Figs. 13-15, 43); length 15.0-19.0 mm; wings not covering abdomen completely (Figs. 3-5) .............. 4

Prosternal keel rounded, not anteriorly projected (Fig. 12); length 12.0-14.0 mm; wings covering abdomen completely (Fig. 2) ................. B. aztecum Lauck (Figs. 2, 7, 12, 17, 22, 27, 32) (Mexico: Campeche, Chiapas, Colima, Guerrero, Michoacán de Ocampo, Nayarit, Oaxaca, Ouroga, Sinaloa, Tamaulipas, Veracruz-Llave)

4. Anteoculus shorter than interoculus .............................. 5 Anteoculus as long as interoculus

B. sanctulum Montandon (Figs. 3, 8, 13, 18, 23, 28, 33) (Argentina: Chaco; Brazil: Espírito Santo, Rio de Janeiro, Santa Catarina, São Paulo) 
5. Prosternal keel acute at apex, never truncated (Figs. 14, 43); abdominal pilosity almost reaching abdominal suture (Fig. 19); male genitalia with dorsal arms of phallotheca divergent (Figs. 24, 36). 6

Prosternal keel truncated or obtuse at apex (Fig. 15); abdominal pilosity not reaching abdominal suture (Fig. 20); male genitalia with dorsal arms of phallotheca parallel or slightly convergent (Fig. 25)

B. horvathi Montandon (Figs. 5, 10, 15, 20, 25, 30, 35) (Argentina: Chaco; Brazil: Bahia, Goiás, Minas Gerais, Paraná, Rio de Janeiro, Rio Grande do Sul, Santa Catarina, São Paulo)

6. Prosternal keel with anterior margin curved (Fig. 14); dorsal arms of phallotheca covering almost entirely sides of ventral diverticulum in dorsal view (Fig. 24) B. candidulum Montandon (Figs. 4, 9, 14, 19, 24, 29, 34) (Argentina: Buenos Aires; Brazil: Minas Gerais, Goiás, Rio de Janeiro, Rio Grande do Sul, São Paulo, Santa Catarina; Uruguay: Artigas).

Prosternal keel with anterior margin smoothly curved (Fig. 39); dorsal arms of phallotheca covering entirely sides of ventral diverticulum in dorsal view (Fig. 36) B. carajaensis

Ribeiro \& Estévez, sp. nov. (Figs. 36-39) (Brazil: Pará).

\section{Belostoma aztecum Lauck, 1959}

(Figs. 2, 7, 12, 17, 22, 27, 32)

Zaitha micantula: Champion 1901: 366 (in part).

Belostoma micantulum: Kirkaldy \& Torre-Bueno 1909: 191 (misidentification).

Belostoma aztecum Lauck, 1959: 6.

Types. - D. R. Lauck designated a male holotype, 23 female and 23 male paratypes (Sirama, La Unión Department, El Salvador) deposited at SEMC, two male paratypes (also from La Unión), and two male paratypes (Santa Rosa [de Lima?], La Unión Department, El Salvador) both deposited in JTPC. These later specimens have not been examined.

Material examined. - MEXICO. Sinaloa State - Mazatlán, VI-1966, (J. T. Polhemus): $1 \mathrm{~m}$ and $1 \mathrm{f}$ (JTPC); Culiacán, I-1951, (A. Humbert): 2 m (SEMC). Tamaulipas State - Guayalejo River, (Young): 1 ? [danified phallus] (BMNH). Nayarit State - $12 \mathrm{mi}$. N of Pena, XI-1948: $1 \mathrm{~m}$ (LACM); 3 m (CASC). Tepic, IX-1953, (B. Malkin): $2 \mathrm{~m}$ and $1 \mathrm{f}$ (LACM); 3 m (CASC); San Blas, IX-1953, (B. Malkin): 1 m (LACM); 2 m (CASC). Colima State - Melague, 1968, (J. T. Polhemus): $1 \mathrm{~m}$ (JTPC); Manzanillo, VII-1956, (A. Lewis): $1 \mathrm{~m}$ and $3 \mathrm{f}$ (LACM). Ignacio de la Veracruz-Llave State [Veracruz, shorter common name] S. Loma Bonita, 1979, (J. T. Polhemus): $3 \mathrm{~m}$ and $1 \mathrm{f}$ (JTPC); Vic. Tampico, VIII-1954, (F. Young): $5 \mathrm{~m}$ and $6 \mathrm{f}$ (JTPC); $15 \mathrm{mi}$. NW of Acayucán, VI-1958, (J. Schaffner): $3 \mathrm{~m}$ (JTPC); 14 mi. SE Llave: $1 \mathrm{~m}$ (JTPC); VIII-1957, (M. Gordon): 3 m (JTPC); Minatitlán, Playón S. Pantanos, III-1948, (M. Gordon): 1 f (NMNH); San Andrés Tuxtla, VIII-1957: 1 m (JTPC); 3 mi. O Paso Ovejas, XII-1958: 3 m (LACM). Guerrero State - Acapulco, V-1955, (F. Truxal): 1 m (LACM). Oaxaca State - E of Tehuantepec, 1964, (J. T. Polhemus): 1 m (JTPC); E of Tehuantepec, IV-1964, (J. and M. Polhemus): $1 \mathrm{~m}$ and $1 \mathrm{f}$ (LACM); 15 mi S of Tehuantepec, (Breedlove): $3 \mathrm{~m}$ (SEMC). Campeche State Had. Encarnación, 12 mi. S Pital, 1938, (H. Smith): 7 m (SEMC).
Michoacán de Ocampo State [Michoacán] - Zamora, XII-1958, (A. Menke and Stange): $1 \mathrm{~m}$ (LACM).

Distribution. - This species had been reported from Mexico (Campeche, Chiapas, Colima, Guerrero, Ignacio de la VeracruzLlave, Michoacán de Ocampo, and Ouroga) and El Salvador (La Unión and Santa Ana) (Lauck 1959). The known distribution in Mexico now includes Nayarit, Oaxaca, Sinaloa, and Tamaulipas States.

Measurements ( $\mathrm{m} / \mathrm{f}$ ). - Total length (from apex of head to apex of abdomen at rest), $12.0-13.0 \mathrm{~mm} / 12.0-14.0 \mathrm{~mm}$; greatest width of body, 5.5-6.5 mm / 6.3-7.0 mm.

General coloration. Almost uniformly brown. Body ovate with wings completely cover abdomen (Fig. 2). Head, thorax, and abdomen. - Length of suture anteclypeus-maxillary plate equal than suture anteclypeus-lorum; maxillary plate not compressed; anteoculus shorter than interoculus; segment I of beak as long as II. Prosternal keel rounded, not projected anteriorly (Fig. 12). Pilosity poorly developed, covering almost half of connexivum, slightly constricted between spiracles, extending posteriorly along less than half of genital operculum (Fig. 17).

Male genitalia (Figs. 22, 27, 32). - Width of ventral diverticulum as long as its length in ventral view; arms of phallotheca straight and parallel, shorter than its posterior region, not covering sides of ventral diverticulum in dorsal view.

Comments. - This is a very distinctive species. Belostoma aztecum is the smallest species in this group and the only one in which the wings completely cover the abdomen. Besides, the arms of phalloteca shorter than its posterior region are diagnostic in male specimens.

\section{Belostoma candidulum Montandon, 1903}

(Figs. 4, 9, 14, 19, 24, 29, 34)

Belostoma candidulum Montandon, 1903b: 363.

Belostoma horvathi: De Carlo 1938: 224 (misidentification). Belostoma machrisi: Menke \& Lauck 1962: 7 (misidentification). Belostoma sanctulum: Ribeiro et al. 1998: 118 (misidentification). Belostoma amici Piza-Jr., 1975 [in part]: 67

Types. - Description of Belostoma candidulum was based on a female holotype (Rio Grande do Sul State, Brazil) determined by Montandon and a male paratype (also from Rio Grande do Sul State) both deposited at NHRS. The holotype bears the labels: "Rio Grande do Sul" and "Belostoma candidulum Mtd., A.L.M.". These specimens have not been examined.

Material examined. BRAZIL. São Paulo State - São Bernardo do Campo Municipality, XII-1961, (Bokermann): $1 \mathrm{~m}$ and $2 \mathrm{f}$ (LACM); São Carlos Municipality, Águas Minerais, V-1957, (Menke): $1 \mathrm{~m}$ and 2 f (LACM); Chapecó River, 1957, (Plaumann): $2 \mathrm{~m}$ and $1 \mathrm{f}$ (JTPC); Campo Bello River, V-1939, (Plaumann): $1 \mathrm{~m}$ and $1 \mathrm{f}$ (LACM); São João dos Campos Municipality, 1960, (Tiemann): 1 m (JTPC). Santa Catarina State - Nova Teutônia Municipality, V-1962, (Plaumann): 1 m (LACM); Linha Facão, 1957, (Plaumann): 1 f (LACM); 25 km São 


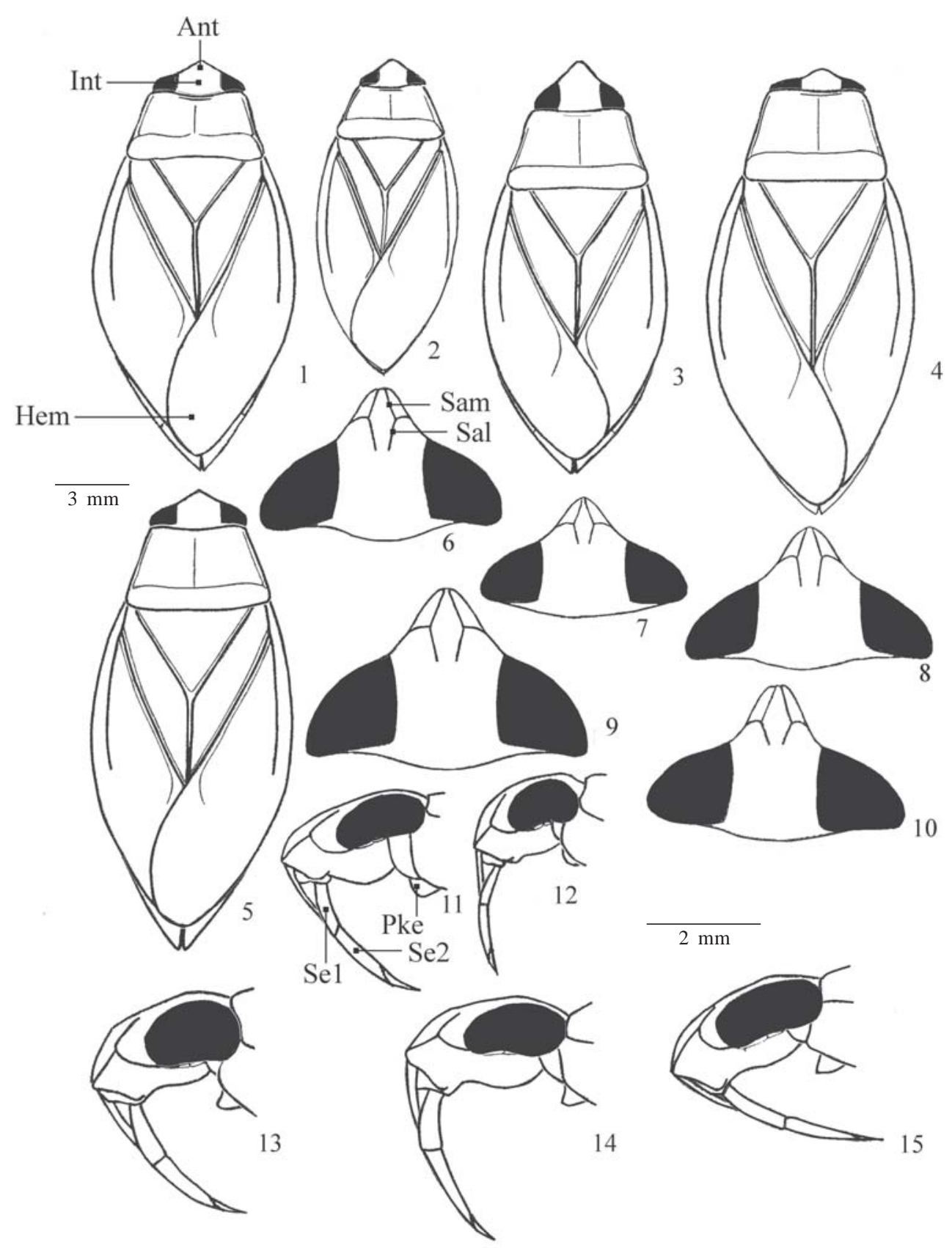

Figs. 1-15. External morphology of Belostoma Latreille species of oxyurum group (sensu Lauck) showing dorsal and lateral views. 1, 6, and 11, Belostoma oxyurum (Dufour, 1863). 2, 7, and 12, B. aztecum Lauck, 1959. 3, 8, and 13, B. sanctulum Montandon, 1903. 4, 9, and 14, B. candidulum Montandon, 1903. 5, 10, and 15, B. horvathi Montandon, 1903. 1-5, dorsal habitus. 6-10, dorsal aspects of head. 11-15, lateral view of prosternal keel. Ant, anteoculus; Hem, hemelytrum; Int, interoculus; Sal, suture anteclypeus-lorum; Pke, prosternal keel; Sam, suture anteclypeus-maxillary plate; Se1, segment 1 of the beak; Se2, segment 2 of the beak.

João da Aliança, IV-1956, (Truxal and Menke): 5 f (LACM). URUGUAY. Artigas Department - Arroyo Tres Cruces Grande, II-1955, (Carbonell, Zolessi, and San Martín): $1 \mathrm{~m}$ (LACM).

Distribution. - This species has been reported from Argentina [Buenos Aires (Ribeiro 2007)]; Brazil [Minas Gerais (Schnack 1976), Goiás and Rio de Janeiro (Ribeiro 2005), Rio Grande do Sul (Montandon 1903b), and São Paulo (Schnack 1976)], and Uruguay [Artigas (Ruffinelli \& Pirán 1959)]. The known distribution in Brazil now includes Santa Catarina State.
Measurements (m/f). - Total length (from apex of head to apex of abdomen at rest), $18.0 \mathrm{~mm} / 18.0 \mathrm{~mm}$; greatest width of body, 8.5-9.0 mm/8.5-9.0 mm.

General coloration almost uniformly light brown. Body elongate with wings not covering abdomen completely (Fig. 4). Head, thorax, and abdomen. - Length of suture anteclypeusmaxillary plate as long as suture anteclypeus-lorum; maxillary plate slightly compressed; anteoculus slightly shorter than interoculus; segment I of beak slightly shorter than II. 

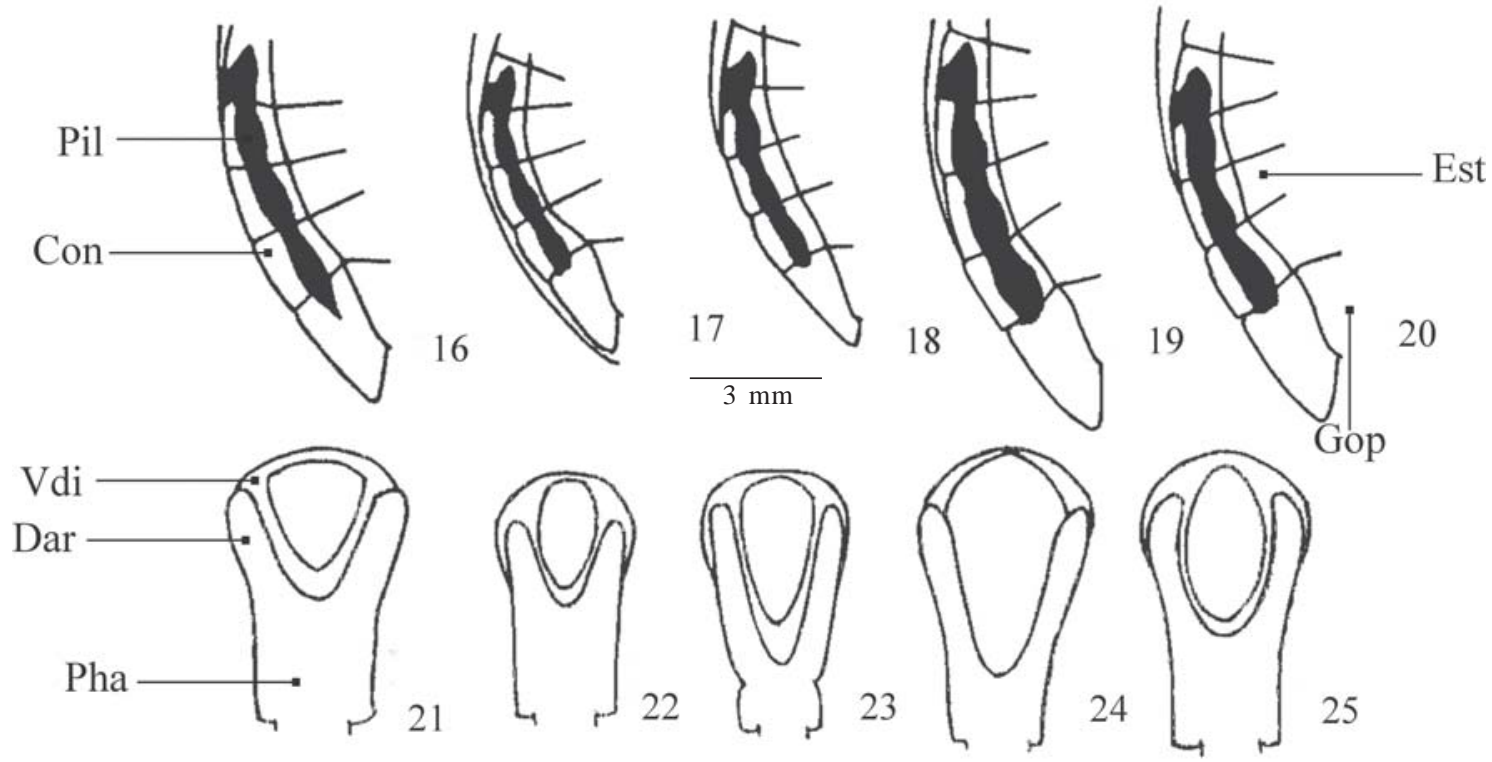

Gop
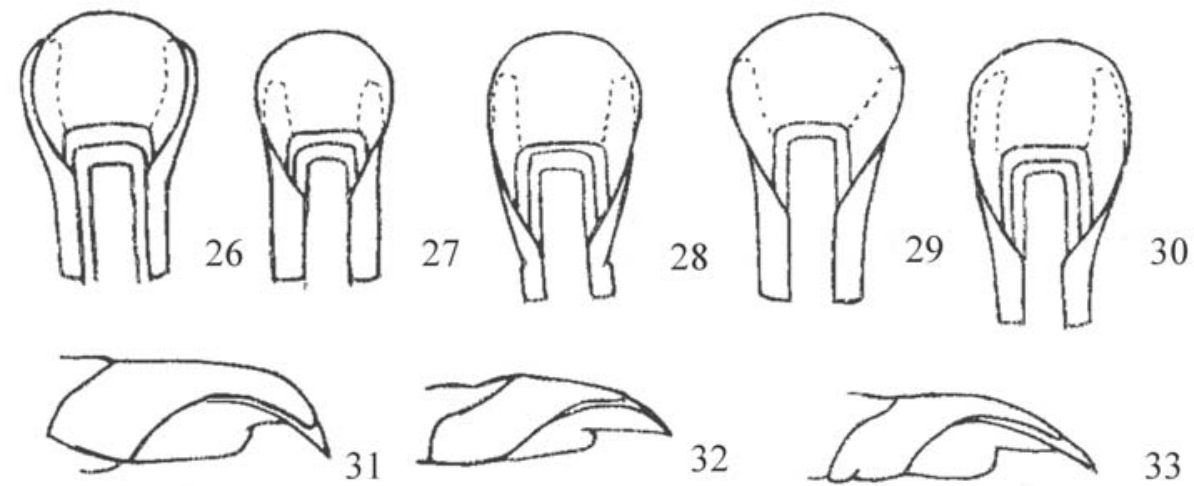

33

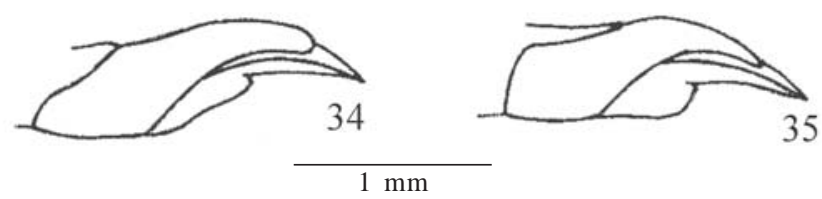

Figs. 16-35. External morphology of Belostoma Latreille species of oxyurum group (sensu Lauck). Ventral aspect of abdomen showing the major differences in pilosity of connexivum. 16, Belostoma oxyurum (Dufour, 1863); 17, B. aztecum Lauck, 1959; 18, B. sanctulum Montandon, 1903; 19, B. candidulum Montandon, 1903; 20, B. horvathi Montandon, 1903. Dorsal aspect of the ventral diverticulum of phallus: 21 , $B$. oxyurum; 22, B. aztecum; 23, B. sanctulum; $24, B$. candidulum; $25, B$. horvathi. Ventral aspect of the ventral diverticulum of phallus: $26, B$. oxyurum; 27, B. aztecum; 28 , B. sanctulum; 29, B. candidulum; 30, B. horvathi. Lateral aspect of the ventral diverticulum of phallus: 31 , B. oxyurum; 32, B. aztecum; 33, B. sanctulum; 34, B. candidulum; 35, B. horvathi. Con, connexivum; Dar, dorsal arms; Est, esternites; Gop, genital operculum; Pha, phallotheca; Pil, pilosity of connexivum; Vdi, ventral diverticulum.

Prosternal keel slightly projected anteriorly, with anterior margin curved (Fig. 14). Pilosity well developed, covering almost entire margin of connexivum, extending posteriorly along less than half of genital operculum (Fig. 19).

Male genitalia (Figs. 24, 29, 34). - Width of ventral diverticulum as long as its length in ventral view; arms of phallotheca diverging, two and a half times longer than its posterior region, covering almost entirely sides of ventral diverticulum in dorsal view.
Comments. - According to Ribeiro (2007), B. candidulum differs from other species of this group because segments I and II of its rostrum are equal in length. However, rostral segments I and II can be subequal depending on the main axes of the head itself. For segments of rostrum measurements, the main axes of the rostrum itself should be horizontal and the measurements should be made along external margins of each segment (as in Estévez \& Polhemus 2001). The discrepancy results from imprecise measuring and is therefore an anomaly. 


\section{Belostoma carajaensis Ribeiro \& Estévez, sp. nov.} (Figs. 36-39)

Type material. - Holotype, BRAZIL. Pará State - Carajás Municipality ["N4A" lagoon], 09-IX-2006, (N. Ferreira-Jr \& L. L. Dumas): $1 \mathrm{~m}$ (JADZRJ 2213); Paratypes: $1 \mathrm{~m}$ and $2 \mathrm{f}$ (JADZRJ 2214); Parauapebas Municipality ["lagoa N4A"], 10-IX-2006, (N. Ferreira-Jr \& L. L. Dumas): $5 \mathrm{~m}$ and $2 \mathrm{f}$ (JADZRJ 2483).

Description of holotype. Measurements. - Total length (from apex of head to apex of abdomen at rest)-15.0; greatest width of body-6.4; median length of pronotum 2.64; greatest pronotal width 4.80. General coloration yellowish-brown. Body poorly robust with wings not covering abdomen completely. Head, thorax, and abdomen. - Body poorly robust. Length of suture anteclypeus-maxillary plate longer than suture anteclypeus-lorum; maxillary plate not compressed; anteoculus slightly shorter than interoculus; segment I of beak shorter than II. Prosternal keel poorly elevated, slightly rounded and poorly angulate anteriorly, with its anterior margin smoothly curved, robust, quite pointed and slightly projected anteriorly, poorly prominent (Fig. 39). Pilosity well developed, covering almost entire margin of connexivum (as Fig. 28, see $B$. candidulum), extending posteriorly along less than half of genital operculum.

Male genitalia (Figs. 36-38). - Width of ventral diverticulum as long as its length in ventral view; arms of phallotheca divergent and large, equal width in all extension, about two and a half times longer than its posterior region, covering completely sides of ventral diverticulum in dorsal view.

Paratypes. Measurements ( $\mathrm{m} / \mathrm{f}$ ) . - Total length (from apex of head to apex of abdomen at rest)-15.6 / 16.1-17.5-; greatest width of body-6.5 / 6.8-7.0; length of rostral segment I- $0.86 / 0.86-0.90$; length of rotral segment II- $0.96 / 0.99$; length of anteoculus- $-0.99 / 1.06-1.18$; length of suture anteclypeusmaxillary plate- $0.61 / 0.51-0.54$; length of suture anteclypeuslorum-0.51 / 0.45-0.48; length of interoculus- $1.01 / 1.12$; median length of pronotum 2.80 / 2.80-2.88; greatest pronotum width $4.96 / 5.20-5.36$.

Etymology. The new species is named after Carajás, the type-locality.

Comments. - The specimens may run to $B$. candidulum in the key to the Belostoma species presented by Nieser \& Melo (1997) and Ribeiro (2007), if we attribute different orientations of the head while being measuring. Belostoma carajaensis $\mathbf{s p .}$ nov. resembles $B$. candidulum in having the segment I of the beak shorter than II and prosternal keel slightly rounded, pointed anteriorly. In B. candidulum, however, the prosternal keel is distinctly more angulate (Fig. 14) and dorsal arms of ventral diverticulum slender (Fig. 24), whereas in B. carajaensis sp. nov. the prosternal keel is less angulate, with its anterior margin smoothly curved (Fig. 39), and dorsal arms are enlarged, covering entirely sides of the ventral diverticulum in dorsal view (Fig. 36). Belostoma sanctulum differs from B. carajaensis sp. nov. in having anteoculus as long as interoculus and the dorsal arms of ventral diverticulum convergent and slender (Fig. 23).

\section{Belostoma horvathi Montandon, 1903 \\ (Figs. 5, 10, 15, 20, 25, 30, 35)}

Belostoma horvathi Montandon, 1903b: 359.

Belostoma oxyurum: Nieser \& Melo 1997: 60 (misidentification).

Belostoma sanctulum: Ribeiro et al. 1998: 118 (misidentification, in part).

Type. - Belostoma horvathi was described based only on a female holotype (Santa Catarina State, Brazil) deposited in HNHM. This specimen has not been examined.

Material examined. - BRAZIL. Bahia State - Santa Rita de Cássia Municipality, Rio Preto, IV-1958, (Dente): $1 \mathrm{~m}$ and $4 \mathrm{f}$ (LACM). São Paulo State - Ipiranga Municipality [as Ypiranga]: $1 \mathrm{~m}$ (JTPC); Jacareí Municipality, Paraíba River, VII-1908: $1 \mathrm{~m}$ and $1 \mathrm{f}$ (LACM).

Distribution. - This species had been reported from Brazil [Goiás, Paraná, and Rio de Janeiro (Ribeiro 2005), Minas Gerais, Rio Grande do Sul, Santa Catarina, and São Paulo (De Carlo 1938)], and Argentina [Chaco (De Carlo 1938)]. The known distribution in Brazil now includes Bahia.

Measurements ( $\mathrm{m} / \mathrm{f}$ ). - Total length (from apex of head to apex of hemelytra at rest), $18.0-19.0 \mathrm{~mm} / 17.0-19.0 \mathrm{~mm}$; greatest width of body, $8.0-9.0 \mathrm{~mm} / 7.5-9.0 \mathrm{~mm}$.

General coloration light to dark reddish brown. Body ovate with wings not covering abdomen completely. Head, thorax, and abdomen. - Length of suture anteclypeus-maxillary plate slightly longer than suture anteclypeus-lorum; maxillary plate not compressed; anteoculus shorter than interoculus; segment I of beak slightly shorter than II. Prosternal keel prominent, truncated (sometimes obtuse) at apex, slightly projected anteriorly (Fig. 15). Pilosity well developed, covering almost entire margin of connexivum, extending posteriorly along less than half of genital operculum (Fig. 20).

Male genitalia (Figs. 25, 30, 35). - Width of ventral diverticulum 1.10 times its length in ventral view; arms of phallotheca parallel or slightly convergent, one and a half times longer than its posterior region, not covering sides of ventral diverticulum in dorsal view.

Comments. - The truncated (or sometimes obtuse) prosternal keel (Fig. 15) and the suture anteclypeus-maxillary plate longer than suture anteclypeus-lorum are, in combination, diagnostic.

\section{Belostoma oxyurum (Dufour, 1863)}

(Figs. 1, 6, 11, 16, 21, 26, 31)

Zaitha oxyura Dufour, 1863: 390.

Belostoma oxyurum: Montandon 1903b: 362.

Type. - Belostoma oxyurum was described based only on a male specimen (Montevideo, Uruguay) deposited in NHMW. According to Ribeiro (2007) and articles 73.1.2 and 73.1.3 of 


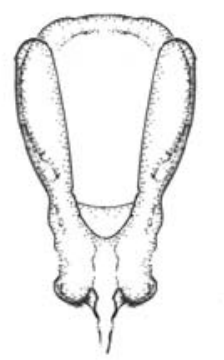

36
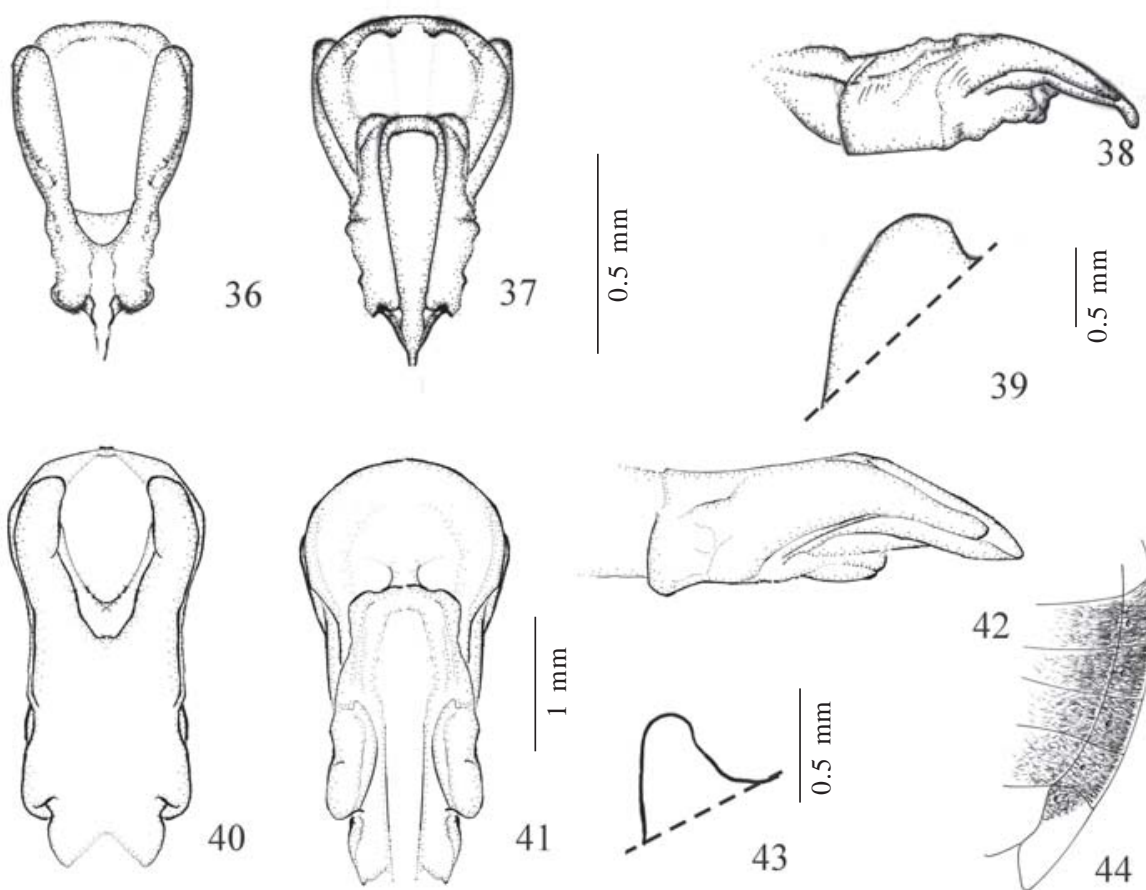

41

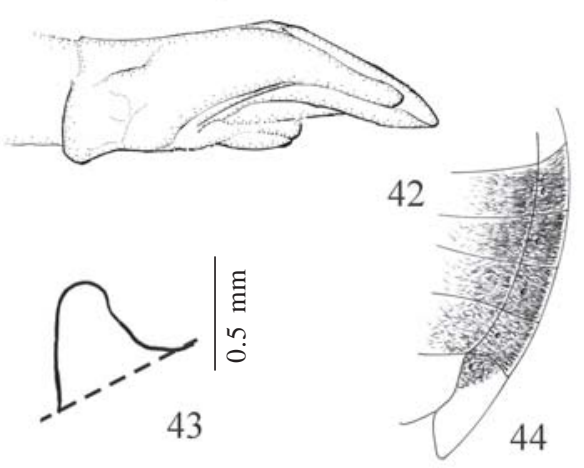

Figs. 36-44. Belostoma carajaensis Ribeiro \& Estévez, sp. nov. and B. noualhieri Montandon, 1903. 36-39, B. carajaensis, sp. nov.: holotype, specimen from State of Pará, Brazil (JADZRJ). 36, dorsal view of ventral diverticulum of phallus; 37, ventral view of ventral diverticulum of phallus; 38, lateral view of ventral diverticulum of phallus; 39, prosternal keel (lateral view). 40-44, B. noualhieri: male specimen from State of São Paulo (JADZRJ). 40, dorsal view of ventral diverticulum of phallus; 41, ventral view of ventral diverticulum of phallus; 42, lateral view of ventral diverticulum of phallus; 43, prosternal keel (lateral view); 44, pilosity extending along the genital operculum, covering entire margin of connexivum and part or all of sternites.

the Code (Iczn 1999), this specimen used by Dufour to describe B. oxyurum is the holotype of this species. It bears the label "Montevideo, coll. Signoret, oxyura, det. Dufour".

Material examined. - BRAZIL. Paraná State - Bituruna Municipality, 1963, (Staviarski): $1 \mathrm{~m}$ and $1 \mathrm{f}$ (MNRJ). Rio Grande do Sul State - Triunfo Municipality, 24-I-199[?]: $10 \mathrm{~m}$ and $10 \mathrm{f}$ (UA). ARGENTINA. Buenos Aires Province - Tigre, 1938, (Drake): 1 ? [danified phallus] (JTPC). Martínez, XII-1956: 2 m (LACM). Buenos Aires, XII-1925, (Drake): $1 \mathrm{~m}$ (LACM); (Kinb.): $1 \mathrm{f}$ (NHRS). Chascomús, 1936, (Daguerre): $1 \mathrm{~m}$ (JTPC); J. A. de Carlo det.: $2 \mathrm{~m}$ (MNRJ 128); 2 m (MACN 39347). Laguna Yalca ["s/ S. rotundifolia"], 26-VII 1966, (Ronderos): $1 \mathrm{~m}$ (MLPA); 17-V-1966: $1 \mathrm{f}$ (MLPA); $01-$ VII-1966: $1 \mathrm{f}$ (MLPA); 02-IX-1966: $1 \mathrm{~m}$ (MLPA); 16-IX-1966: $1 \mathrm{~m}$ (MLPA); 25-V-1969, (Schnack): 1 f (MLPA); Monte, 14-VI-1967: 1 m (MLPA). Gral. Madariaga: 2 m (MLPA). URUGUAY. Montevieo Department - Holotype, (Signoret), Dufour det.: $1 \mathrm{~m}$ (NHMW); (Kinb.): $1 \mathrm{~m}$ and $3 \mathrm{f}$ (NHRS). Maldonado Department - Cerro Ánimas, X-1959, (Carbonell): $1 \mathrm{f}$ (LACM).

Distribution. - This species has been reported from Argentina (Buenos Aires, Chascomús, Entre Ríos, and Martín García Island) (De Carlo 1930, 1938; Schnack 1973, 1976) and Uruguay (Montevideo) (Mayr 1871; De Carlo 1938). The known distribution now includes Brazil (Paraná and Rio Grande do Sul) and Uruguay (Maldonado).

Measurements ( $\mathrm{m} / \mathrm{f}$ ). - Total length (from apex of head to apex of abdomen at rest), $15.0-18.0 \mathrm{~mm} / 15.0-18.0 \mathrm{~mm}$; greatest width of body, 7.5-9.0 mm/7.0-9.0 mm.
General coloration uniformly brown. Body ovate with wings not covering abdomen completely. Head, thorax, and abdomen. - Length of suture anteclypeus-maxillary plate shorter than suture anteclypeus-lorum; maxillary plate not compressed; anteoculus shorter than interoculus; segment I of beak shorter than II. Prosternal keel rounded, poorly prominent, angulate, not projected anteriorly, with its anterior margin slightly curved (frequently with tubercles at apex) (Fig. 11). Pilosity well developed, covering half of connexivum, slightly constricted between spiracles, extending posteriorly along about half, but far away of genital operculum (Fig. 16).

Male genitalia (Figs. 21, 26, 31). - Width of ventral diverticulum as long as its length in ventral view; arms of phallotheca divergent, as long as its posterior region, covering sides of ventral diverticulum in dorsal view.

Comments. - Belostoma oxyurum is the only species in this group with the abdominal pilosity extending appreciably onto the last visible abdominal segment but far away of genital operculum, and not on sternites (Fig. 16).

\section{Belostoma sanctulum Montandon, 1903}

(Figs. 3, 8, 13, 18, 23, 28, 33)

Belostoma sanctulum Montandon, 1903b: 362.

Belostoma amici: Piza-Jr. 1975: 67 (misidentification, in part). 
Type. - Belostoma sanctulum was described based on syntypes deposited in HNHM, in ISNB, and in Breddin's collection (Ribeiro 2007). A male specimen identified and designated as a cotype by Montandon (Espírito Santo State, Brazil) and deposited at NHRS is herein designated as lectotype. It bears the following labels: "Esperito Santo, Brazil, ex. Coll. Fruhstörfer" and "Belostoma sanctulum Mtd., A.L.M.".

Material examined. - BRAZIL: $2 \mathrm{~m}$ and $1 \mathrm{f}$ (BMNH). Espírito Santo State - 1903, (Frühstörfer), A. L. Montandon det. 1903: $1 \mathrm{~m}$ (JTPC); paralectotypes, $2 \mathrm{~m}$ (ISNB); lectotype, A. L. Monandon det.: $1 \mathrm{~m}$ (NHRS). Santa Catarina State - Nova Teutônia Municipality, III1966, (Plaumann): $1 \mathrm{~m}$ and $1 \mathrm{f}$ (LACM).

Distribution. - This species has been reported from Argentina (Chaco) (Ribeiro 2007) and Brazil [Espírito Santo and Santa Catarina (De Carlo 1938; Schnack 1976); Rio de Janeiro and São Paulo (Ribeiro 2005)].

Measurements ( $\mathrm{m} / \mathrm{f}$ ). - Total length (from apex of head to apex of abdomen at rest), $17.0-18.0 \mathrm{~mm} / 17.0-18.0 \mathrm{~mm}$; greatest width of body, 7.5-9.0 mm/6.3-7.0 mm. General coloration almost uniformly brown. Body ovate with wings not covering abdomen completely. Head, thorax, and abdomen. - Length of suture anteclypeus-maxillary plate equal than suture anteclypeus-lorum; maxillary plate not compressed; anteoculus as long as interoculus; segment I of beak shorter than II. Prosternal keel prominent and acute, projected anteriorly, with its anterior margin curved (Fig. 13). Pilosity poorly developed, covering almost half of connexivum, slightly constricted between spiracles, extending posteriorly along less than half of genital operculum (Fig. 18).

Male genitalia (Figs. 23, 28, 33). - Width of ventral diverticulum as long as its length in ventral view; arms of phallotheca diverging, two and a half times longer than its posterior region, not covering sides of ventral diverticulum in dorsal view.

Comments. - Belostoma sanctulum is similar to B. oxyurum in size but the body of the former species is not as robust as that of $B$. oxyurum. This species has a narrower band of abdominal pilosity than $B$. oxyurum (Figs. 16, 18). The conspicuous shorter pronotum as an attribute of $B$. sanctulum, reported by Nieser and Melo (1997) and repeated by Ribeiro (2007), is clearly a case of imprecise measurements. According to De Carlo (1938) and Schnack (1973, 1976), B. sanctulum specimens have the greatest pronotal width less than twice its length, which is here corroborated.

\section{Belostoma noualhieri Montandon, 1903}

(Figs. 40-44)

Belostoma noualhieri Montandon, 1903a: 21.

Type. - Belostoma noualhieri was described based only on female holotype (Rio Grande do Sul State, Brazil) deposited in MNHN.
Material examined. - BRAZIL. São Paulo State - Campinas Municipality, Unicamp [Universidade de Campinas], marsh, II-2004, (R. Santiago): $1 \mathrm{~m}$ and $1 \mathrm{f}$ (JADZRJ). Santa Catarina State - Nova Teutônia Municipality [ $27^{\circ} 11^{\prime}$ S, 52 23' W, 300-500 m], XI-1934, (F. Plaumann), J. A. De Carlo det. as B. horvathi: $1 \mathrm{f}$ (MACN). Holotype, Rio Grande do Sul State - 1898, (Noualhier), A. L. Montandon det. 1920 [on 20-XII-1920], labelled as Z. oxyura: $1 \mathrm{f}$ (MNHN).

Distribution.-This species had been reported from Brazil [Rio Grande do Sul (Montandon 1903a, De Carlo 1938) and São Paulo (De Carlo 1950)]. The known distribution now includes Santa Catarina.

Description of the male. Measurements. - Total length (from apex of head to apex of abdomen at rest), $21.2 \mathrm{~mm}$; greatest width of body $10.1 \mathrm{~mm}$. General coloration dark brown. Body elliptical with wings not covering abdomen completely. Head, thorax, and abdomen. - Length of suture anteclypeus-maxillary plate shorter than suture anteclypeus-lorum; maxillary plate not compressed; anteoculus as long as interoculus; segment I of beak shorter than II. Prosternal keel prominent and elevated, smoothly acute at apex, not projected anteriorly, with its anterior margin slightly curved (Fig. 43). Pilosity well developed, covering entire margin of connexivum and part of sternites, extending posteriorly along about half of genital operculum (Fig. 44).

Male genitalia (Figs. 40-42). - Width of ventral diverticulum about 0.8 times its length in ventral view; dorsal arms of phallotheca convergent and large, one time as long as its posterior region, covering almost entirely sides of ventral diverticulum in dorsal view.

Comments. - Belostoma noualhieri is the largest species of this group and is the only species in this group with the abdominal pilosity covering entire margin of connexivum and at least part of sternites (Fig. 44). The specimens herein studied agree with the specimens studied by De Carlo (1950), including the length of rostral segments I and II. Unfortunately Montandon and De Carlo studied neither male specimens nor their phalluses. The presence of a circular, flattened and broad ventral diverticulum of phallus as well as the presence of the anterior interocular width: width of an eye ratio equal to 1.5 were mentioned by Lauck (1962) and Nieser (1975) as characters considered diagnostics for oxyurum species. A circular and flattened ventral diverticulum of phallus studied here in $B$. noualhieri male specimen (Figs. 40-41) corroborates our opinion about the existence of a closely relationship between $B$. noualhieri and the species of oxyurum group, regardless of the presence not reported in B. noualhieri of the anterior interocular width equal to 1.5 times the width of an eye. We therefore are confident in including $B$. noualhieri under oxyurum group.

Acknowledgments. The manuscript benefited from the useful comments of A. L. Melo (Universidade Federal de Minas Gerais, Minas Gerais, Brazil), J. L. Nessimian (Universidade Federal do Rio de Janeiro, Rio de Janeiro, Brazil), and J. T. Polhemus (Colorado, USA). We thank the following collectors for the loan of specimens: A. Orosz (HNHM), 
A. O. Bachmann (MACN), B. V. Brown (LACM), C. Olson (UA), D. Pluot-Sigwalt (MNHN), H. Mendel (BMNH), H. Zettel (NHMW), J. L. Nessimian (JADZRJ), G. Lindberg (NHRS), G. Mejdalani (MNRJ), J. T. Polhemus (JTPC), N. D. Penny (CASC), P. Grootaert (ISNB), and R. W. Brooks (SEMC). We gratefully acknowledge Glauco Machado (Universidade de São Paulo, São Paulo, Brazil) for collecting male specimens of B. noualhieri; Nelson Ferreira-Jr. and Leandro L. Dumas (Universidade Federal do Rio de Janeiro, Rio de Janeiro, Brazil) for collecting specimens of $B$. carajaensis sp. nov.; and IBAMA (Instituto Brasileiro do Meio Ambiente) for providing licenses (003/2006-MAB/ FAUNA) to collecting. This work was sponsored in part by The Brazilian Council of Scientific and Technological Development (CNPq).

\section{REFERENCES}

Champion, G. C. 1901. Order Rhynchota. Suborder HemipteraHeteroptera. Belostomatidae. Biologia Centrali-Americana 2: $1-416$.

De Carlo, J. A. 1930. Familia Belostomatidae, géneros y especies para la Argentina. Revista de la Sociedad Entomológica Argentina 13: $101-124$.

De Carlo, J. A. 1938. Los Belostómidos Americanos Hemiptera. Anales del Museo argentino de ciencias naturales 'Bernardino Rivadavia' 39: 81-252.

De Carlo, J. A. 1950. Descripción de especies nuevas de "Ranatridae" y "Belostomidae" y algunas aclariaciones referentes a otras poco conocidas (Hemiptera). Revista Brasileira de Biologia 10: 521532.

De Carlo, J. A. 1957. Especies nuevas de la familia Belostomatidae (Hemiptera) y algunas consideraciones sobre otras poco conocidas. Revista de la Sociedad Entomológica Argentina 19: 47-59.

Dufour, L. 1863. Essai Monographique sur les Belostomatides. Annales de la Société entomologique de France 3: 373-400.

Estévez, A. L. \& J. T. Polhemus. 2001. The small species of Belostoma (Heteroptera: Belostomatidae). 1. Key to species groups and a revision of the denticolle group. Iheringia, Série Zoologia 91: $151-158$.

Iczn (International Commission on Zoological Nomenclature). 1999. International Code of Zoological Nomenclature. 4th Edition, London, International Trust for Zoological Nomenclature, xxix+ $306 \mathrm{p}$.

Kirkaldy, G. W. \& J. R. de la Torre-Bueno. 1909. A Catalogue of American Aquatic and Semiaquatic Hemiptera. Proceedings of the Entomological Society of Washington 10: 173-215.

Lauck, D. R. 1959. Three new species of Belostoma from Mexico and Central America (Hemiptera-Belostomatidae) with a list of North American species. Bulletin of the Chicago Academy of Sciences 11: 1-9.

Lauck, D. R. 1962. A monograph of the genus Belostoma (Hemiptera). Part I. Introduction and B. dentatum and subspinosum groups. Bulletin of the Chicago Academy of Sciences 11: 34-81.

Lauck, D. R. 1963. A monograph of the genus Belostoma (Hemiptera). Part II. B. aurivillianum, stollii, testaceopallidum, dilatatum, and discretum groups. Bulletin of the Chicago Academy of Sciences 11: 82-101.

Lauck, D. R. 1964. A monograph of the genus Belostoma (Hemiptera). Part III. B. triangulum, bergi, minor, bifoveolatum, and flumineum groups. Bulletin of the Chicago Academy of Sciences 11: $102-154$.

Mayr, G. 1871. Die Belostomiden. Verhandlungen der zoologischbotanischen Gesellschaft Wien 21: 399-440.

Menke, A. S. \& D. R. Lauck. 1962. The Machris Brazilian Expedition. Entomology: Belostomatidae (Hemiptera). Contributions in Science 55: 3-8.

Montandon, A. L. 1903a. Deux nouvelles espèces du genre Belostoma (=Zaitha Amyot et Serville et auct.) des collections du Muséum de Paris. Bulletin du Muséum d'Histoire Naturelle 9: 21-23.

Montandon, A. L. 1903b. Espèces nouvelles ou peu connues du genre Belostoma. Appartennant aux collections du Musée National Hongrois. Annales Musei Nationalis Hungarici 1: 359-363.

Nieser, N. 1975. The water bugs (Heteroptera-Nepomorpha) of the Guyana Region. Studies on the Fauna of Suriname and other Guyanas 16: 1-310.

Nieser, N. \& A. L. Melo. 1997. Os heterópteros aquáticos de Minas Gerais. Guia introdutório com chave de identificação para as espécies de Nepomorpha e Gerromorpha. Belo Horizonte, Ed. UFMG, $180 \mathrm{p}$.

Piza-Jr., S. de T. 1975. Species nova Belostomatidarium brasiliensium. Revista de Agricultura 50: 67-68.

Ribeiro, J. R. I., Nessimian, J. L. \& E. C. Mendonça. 1998. Aspectos da distribuição dos Nepomorpha (Hemiptera: Heteroptera) em corpos d'água na Restinga de Maricá, Estado do Rio de Janeiro, p. 113128. In: J. L. Nessimian \& A. L. Carvalho (eds.). Ecologia de insetos aquáticos. Series Oecologia Brasiliensis. V. 5. Rio de Janeiro, PPGE-UFRJ, xvii+309 p.

Ribeiro, J. R. I. 2005. Família Belostomatidae Leach, 1815 (Insecta: Hemiptera: Heteroptera): chave e catálogo de identificação para as espécies ocorrentes no Estado do Rio de Janeiro, Brasil. Arquivos do Museu Nacional, Rio de Janeiro 63: 247-262.

Ribeiro, J. R. I. 2007. A review of the species of Belostoma Latreille, 1807 (Hemiptera: Heteroptera: Belostomatidae) from the four southeastern Brazilian States. Zootaxa 1477: 1-70.

Ruffinelli, A. \& A. A. Pirán. 1959. Hemipteros heterópteros del Uruguai. Boletin de la Facultad de Agronomia de Montevideo 51: 4547.

Schnack, J.A. 1973. Clave para determinación de especies argentinas del género Belostoma Latreille (Hemiptera: Belostomatidae). Revista del Museo de La Plata 12: 1-10.

Schnack, J. A. 1976. Insecta-Hemiptera-Belostomatidae. Fauna de agua dulce de la Republica Argentina, Volume 35, Fascículo 1. Buenos Aires, Fundación para la educación, la ciencia y la cultura, $66 \mathrm{p}$.

Zanella, F. C. V.; M. L. Oliveira \& M. C. Gaglianone. 2000. Standardizing lists of locality data for examined specimens in systematics and biogeography studies of new world taxa. Biogeographica 76: 145160 . 